\title{
Mff|cosias Poltekkes Makassar \\ UJI DAYA HAMBAT EKSTRAK DAUN TAMMATE (Lannea coromandelica) TERHADAP BAKTERI Propionilbacterium acnes DAN Escherichia coli
}

\author{
Inhibitory Test Of Tammate Leaf Extract (Lannea Coromandelica) Against Propionilbacterium \\ Acnes And Escherichia Coli Bacteria \\ Nurlaela $^{1}$, Abd. Karim², Taufiq Dalming ${ }^{3}$ \\ ${ }^{1}$ Bagian Farmasi, Prodi DIII Faramasi Stikes Pelamonia Kesdam VII/WRB \\ (Email: nurlaela030199@ gmail.com) \\ ${ }^{2}$ Bagian Farmasi, Prodi DIII Faramasi Stikes Pelamonia Kesdam VII/WRB \\ (Email: arimjie@gmail.com) \\ ${ }^{3}$ Bagian Farmasi, Prodi DIII Faramasi Stikes Pelamonia Kesdam VII/WRB \\ (Email: $\underline{\text { ahta2010@gmail.com) }}$
}

\author{
Alamat Korespondensi: \\ Nurlaela A. Md. Farm \\ Prodi DIII Farmasi \\ Stikes Pelamonia Kesdam VII/WRB \\ Makassar, 90245 \\ HP: 085396334688 \\ Email: nurlaela030199@gmail.com \\ https://doi.org/10.32382/mf.v14i2.598
}

\section{ABSTRACT}

Research has been conducted the inhibitory test of Tammate leaf extract (Lannea Coromandelica) on the Propionilbacterium Acnes and Escherichia Coli bacteria. This research is an experimental study that aims to determine the antibacterial inhibitory activity of $70 \%$ ethanol extract of tammate leaves (Lannea Coromandelica) against Propionilbacterium Acnes and Escherichia Coli bacteria. The testing is performed using the disc diffusion method, with media control NA (Nutrient Agar). Generated zones with different diameters were obtained from $70 \%$ ethanol extract of tammate leaves (Lannea coromandelica) in Propionilbacterium acnes bacteria with a concentration of $10 \%, 20 \%$, that is 10,540 $\mathrm{mm}, 12,418 \mathrm{~mm}$. Against bacteria concentration of Escherichia coli of 10\%, 20\% is 9,203 mm, 10,208 $\mathrm{mm}$.

Keywords : Tammate Leaf Extract, Inhibitory Power Test, Disc Diffusion Method, Propionilbacterium Acnes and Escherichia Coli.

\begin{abstract}
ABSTRAK
Telah dilakukan penelitian Uji daya hambat ekstrak daun tammate (Lannea Coromandelica) terhadap bakteri Propionilbacterium Acnes dan Escherichia Coli. Penelitian ini merupakan penelitian eksperimental laboratorium yang bertujuan untuk mengetahui aktivitas daya hambat antibakteri ekstrak etanol $70 \%$ daun tammate (Lannea Coromandelica) terhadap bakteri Propionilbacterium Acnes dan Escherichia Coli. Pengujian dilakukan dengan metode disc diffusion yaitu dengan menggunakan Kontrol media adalah NA (Nutrient Agar). Dihasilkan zona hambatan dengan diameter berbeda yang diperoleh dari ekstrak etanol $70 \%$ daun tammate (Lannea coromandelica) pada bakteri Propionilbacterium acnes konsentrasi 10\%, 20\% yaitu 10,540 mm, 12,418 mm. Terhadap bakteri Escherichia coli konsentrasi 10\%, $20 \%$ yaitu $9,203 \mathrm{~mm}, 10,208 \mathrm{~mm}$.
\end{abstract}

Kata kunci : Ekstrak daun tammate, Uji daya hambat, metode disc diffusion, Propionilbacterium Acnes dan Escherichia Coli.

\section{PENDAHULUAN}

Dahulu manusia menggunakan bahan alam untuk pengobatan, baik dari tanaman, hewan, ataupun mineral. Pengobatan dengan menggunakan bahan alam diperkirakan berusia sama dengan usia peradaban manusia itu sendiri. Dari catatan sejarah dapat diketahui bahwa fitoterapi atau terapi menggunakan tumbuhan telah dikenal oleh masyarakat sejak masa sebelum masehi (Gana, 2008). 
Penggunaan tanaman obat di Indonesia dalam upaya pemeliharaan kesehatan, maupun sebagai pengobatan menggunakan tanaman obat kecenderungannya terus meningkat terutama sejak krisis ekonomi tahun 1997 yang menyebabkan harga obat sintetik melonjak sangat tinggi karena sebagian besar bahan bakunya masih diimpor. Seiring dengan hal itu, penelitian yang membuktikan khasiat dan keamanan obat tradisional atau obat asli Indonesia juga meningkat (BPOM RI, 2010).

Salah satu tanaman obat tradisional yang banyak dimanfaatkan masyarakat Indonesia, khususnya masyarakat Galesong, Sulawesi Sulawesi adalah Tammate (Lannea coromandelica), dalam masyarakat Bugis dikenal dengan sebutan "Aju Jawa”. Tammate (Lannea coromandelica) dilaporkan memiliki antivitas antioksidan dan uji toksisitas (Prawirodiharjo, 2014). Penelitian yang telah ada menunjukkan bahwa tanaman tammate memiliki potensi sebagai antibakteri.

Propionibacterium acnes (Gram positif) mewakili bakteri penyebab inflamasi atau jerawat pada kulit wajah, karena beberapa turunan asam sinamat berkhasiat sebagai antiinflamasi (Ramadhan, 2015). Propionibacterium acnes merupakan bakteri yang berperan dalam pembentukkan jerawat yang merupakan anggota flora kulit dan selaput lendir manusia. Bakteri ini ikut serta dalam fotogenesis jerawat dengan menghasilkan lipase, yang dapat memecah asam lemak bebas dari lipid kulit. Asam lemak ini dapat menimbulkan radang jaringan dan ikut menyebabkan jerawat (Mumpuni, 2010).

Escherichia coli mewakili bakteri Gram negatif merupakan bakteri normal usus namun dalam keadaan tidak normal bersifat patogen, umumnya menyebabkan diare dan sebagai indikator pencemaran air dengan tinja (Rahmadani, 2015).

Penggunaan empiris secara luas menurut masyarakat di daerah Galesong khasiat Tammate (Lannea coromandelica) pada daun dan kulit batangnya yaitu dimanfaatkan dengan cara ditumbuk ataupun direbus untuk mengobati luka luar, luka dalam, obat luka, obat bintitan, obat diare.

Berdasarkan uraian di atas dan penelusuran literatur diketahui masih terbatas informasi tentang potensi daya hambat ekstrak daun tammate terhadap bakteri, termasuk bakteri Propionilbacterium acnes dan Escherichia coli. Oleh karena itu dilakukan penelitian uji daya hambat ekstrak etanol $70 \%$ dengan metode maserasi pada tanaman daun tammate (Lannea coromandelica) terhadap bakteri Propionilbacterium acnes dan Escherichia coli.

\section{METODE}

Jenis Penelitian

Jenis penelitian ini merupakan penelitian eksperimental laboratorium yaitu dengan membuat ekstrak daun tammate (Lannea coromandelica) dan dilakukan uji daya hambat terhadap bakteri Propionilbacterium acnes dan Escherichia coli. Penelitian ini dilakukan pada bulan Juni 2018 di Laboratorium Mikrobiologi Jurusan Farmasi Fakultas Kedokteran dan Ilmu Kesehatan Universitas Islam Negeri Alauddin Makassar.

\section{Pengolahan Sampel}

Daun tammate (Lannea coromandelica) segar, daun ke lima dari pucuk dipetik dari batangnya yang diambil dari daerah Galesong Kabupaten Takalar, Sulawesi Selatan. Daun tammate dicuci bersih menggunakan air yang mengalir, diiris tipis-tipis dengan menggunakan pisau/gunting stainless kemudian dikeringkan.

\section{Pembuatan Ekstrak}

Ditimbang sampel 500 gram dimasukkan dalam wadah maserasi, dibasahi dengan pelarut etanol $70 \%$ sampai sampel terendam sempurna. Ekstraksi dilakukan selama $3 \times 24$ jam sambil sesekali diaduk, kemudian disaring, dipisahkan antara ampas dan filtrat. Filtrat yang diperoleh kemudian dikumpulkan, kemudian dipekatkan dengan rotavapor kemudian diuapkan diatas penangas air hingga diperoleh ekstrak kental.

\section{Pembuatan Medium}

Ditimbang media NA (Nutrient agar) 2 gram, dilarutkan dengan $100 \mathrm{~mL}$ aquadest. Cek $\mathrm{pH} \quad(7,0 \pm 0,2)$ lalu didihkan sampai jenuh kemudian disterilkan dengan autoklaf pada suhu $121^{\circ} \mathrm{C}$ selama 15 menit.

\section{Penyiapan Bakteri Uji}

a. Peremajaan Bakteri

Propionilbacterium acnes dan Escherichia coli diambil satu ose diinokulasikan dengan cara digoreskan pada medium NA secara miring dan diinkubasikan pada suhu $37^{\circ} \mathrm{C}$ selama $1 \times 24$ jam sehingga diperoleh biakan murni Propionilbacterium acnes dan Escherichia coli.

b. Pembuatan Suspensi Biakan Bakteri Diambil satu ose bakteri Propionilbacterium acnes dan Escherichia coli kemudian dimasukkan kedalam tabung 
reaksi steril yang berisi larutan aquadets sebanyak $10 \mathrm{~mL}$ dan didapatkan suspensi bakteri yang homogen. Suspensi diencerkan hingga didapatkan suspense bakteri.

\section{Pembuatan Larutan Kontrol}

Larutan kontrol positif yang digunakan ada dua yaitu: antibiotik klindamisin dengan konsentrasi 2 ppm untuk pengujian pada bakteri Propionibacterium acnes dibuat dengan cara menimbang $2 \mathrm{mg}$ klindamisin dilarutkan dengan DMSO dan ditambahakan aquadest hingga 10 mL. Dilakukan pengenceran dengan cara mengambil $1 \mathrm{~mL}$ kemudian ditambahakan aquadest hingga $100 \mathrm{~mL}$ didapatkan kosentrasi $2 \mathrm{ppm}$.

Antibiotik kloramfenikol dengan konsentrasi 30 ppm untuk pengujian pada bakteri Escherichia coli dibuat dengan cara menimbang $3 \mathrm{mg}$ kloramfenikol dilarutkan dengan DMSO dan ditambahakan aquadest hingga $100 \mathrm{~mL}$ didapatkan kosentrasi 30 ppm.

\section{Pembuatan Larutan Uji Ekstrak Daun Tammate}

Larutan uji ekstrak etanol $70 \%$ daun tammate (Lannea coromandelica) dibuat dengan konsentrasi $0,025 \%, 0,05 \%, 0,1 \%, 1 \%, 10 \%$ dan $20 \%$ dengan cara menimbang 2 gram ekstrak kemudian dilarutkan dengan DMSO dan ditambahkan aquades hingga $10 \mathrm{~mL}$ untuk $20 \%$. Menimbang 1 gram ekstrak kemudian dilarutkan dengan DMSO dan ditambahkan aquades hingga $10 \mathrm{~mL}$ untuk $10 \%$. Menimbang $100 \mathrm{mg}$ ekstrak kemudian dilarutkan dengan DMSO dan ditambahkan aquades hingga $10 \mathrm{~mL}$ untuk 1\%. Menimbang $10 \mathrm{mg}$ ekstrak kemudian dilarutkan dengan DMSO dan ditambahkan aquades hingga $10 \mathrm{~mL}$ untuk $0,1 \%$. Menimbang $5 \mathrm{mg}$ ekstrak kemudian dilarutkan dengan DMSO dan ditambahkan aquades hingga $10 \mathrm{~mL}$ untuk $0,05 \%$. Dan menimbang 2,5 mg ekstrak kemudian dilarutkan dengan DMSO dan ditambahkan aquades hingga $10 \mathrm{~mL}$ untuk $0,025 \%$.

\section{Pengujian Daya Hambat}

Disiapkan medium NA steril, didinginkan hingga suhu sekitar $45^{\circ} \mathrm{C}$. Medium NA sebanyak $10 \mathrm{~mL}$ dicampur dengan suspense bakteri uji sebanyak $20 \mu \mathrm{l}$. Selanjutnya dituang secara aseptis ke dalam cawan petri steril dan dibiarkan memadat. Dibuat zat yang akan diuji dimasukkan ke dalamnya dengan konsentrasi $0,025 \%, 0,05 \%, 0,1 \%, 1 \%, 10 \%$ dan $20 \%$. Kemudian diinkubasikan pada suhu $37^{\circ} \mathrm{C}$ selama 1x24 jam. Kontrol positif yaitu: klindamisin (2 ppm) untuk Propionibacterium acnes, dan kloramfenikol (30 ppm) untuk pengujian pada bakteri Escherichia coli.

\section{Pengamatan dan Pengukuran Diameter Hambatan}

Pengamatan dan pengukuran diameter hambatan dilakukan dengan menggunakan jangka sorong setelah diinkubasikan selama 24 jam dan dicatat pada tabel pengamatan.

\section{HASIL}

Hasil Uji Daya Antibakteri Bakteri Propionilbacterium acnes dapat dilihat pad tabel di bawah

\section{PEMBAHASAN}

Penelitian ini menguji ekstrak $70 \%$ daun tammate (Lannea coromandelica) terhadap aktivitas pertumbuhan bakteri. Sampel uji dalam penelitan ini digunakan bagian daun dari tanaman tammate (Lannea coromandelica) diperoleh di daerah Galesong Kabupaten Takalar, Sulawesi Selatan. Tanaman ini banyak tumbuh liar ataupun sengaja ditanam sebagai tanaman pagar. Pengujian bertujuan untuk menentukan aktivitas daya hambat antibakteri ekstrak etanol $70 \%$ daun tammate (Lannea coromandelica) terhadap bakteri Propionilbacterium acnes dan Escherichia coli. Metode uji aktivitas antibakeri yang digunakan adalah metode disc diffusion. Pada metode ini sensitivitas bakteri terhadap sampel uji dilihat dengan adanya zona bening disekitar area mengindikasikan hambatan pertumbuhan mikroorganisme oleh agen antimikroba pada permukaan media agar.

Bakteri yang digunakan untuk menguji ekstrak $70 \%$ daun tammate (Lannea coromandelica) yaitu Propionilbacterium acnes dan Escherichia coli. Propionilbacterium acnes mewakili Gram positif merupakan bakteri penyebab inflamasi atau jerawat pada kulit wajah, karena beberapa turunan asam sinamat berkhasiat sebagai antiinflamasi. Adapun bakteri Escherichia coli mewakili Gram negatif merupakan bakteri normal usus namun dalam keadaan tidak normal bersifat patogen, umumnya menyebabkan diare dan sebagai indikator pencemaran air dengan tinja.

Konsentrasi uji yang dipakai pada penelitian ini adalah $0,025 \%, 0,05 \%, 0,1 \%, 1 \%$, $10 \%$, dan $20 \%$. Pemilihan konsentrasi yang digunakan karena berdasarkan penelitian sebelumnya dan juga berdasarkan literatur yang mengatakan bahwa ekstrak dikatakan berpotensi sebagai antimikroba jika pada kadar pemberian $\leq 1000 \mu \mathrm{g} / \mathrm{ml}$ mampu menghambat pertumbuhan antimikroba. 
Dari hasil yang tertera di atas menunjukan bahwa ekstrak etanol $70 \%$ daun tammate (Lannea coromandelica) tidak memiliki potensi antibakteri pada konsentrasi $0,025 \%, 0,05 \%, 0,1 \%$, dan $1 \%$, akan tetapi bisa mengahambat bakteri Propionilbacterium acnes ditunjukan adanya zona bening pada konsentrasi $10 \%, 20 \%$ masing-masing berdiameter 10,540 mm, 12,418 mm. Terhadap bakteri Escherichia coli adanya zona bening pada konsentrasi $10 \%$, $20 \%$ masing-masing berdiameter $9,203 \mathrm{~mm}$, $10,208 \mathrm{~mm}$.

Kontrol positif klindamisin dengan konsentrasi 2 ppm untuk bakteri Gram positif Propionilbacterium acnes menunjukkan adanya zona bening diameter $15,474 \mathrm{~mm}$, dan kloramfenikol dengan konsentrasi 30 ppm untuk bakteri Gram negatif Escherichia coli menunjukkan adanya zona bening diameter $15,676 \mathrm{~mm}$.

Rata-rata diameter hambatan ekstrak etanol $70 \%$ daun tammate (Lannea coromandelica) pada bakteri Propionilbacterium acnes pada konsentrasi $10 \%$, 20\% yaitu $10,540 \mathrm{~mm}, 12,418 \mathrm{~mm}$. Terhadap bakteri Escherichia coli pada konsentrasi $10 \%$, 20\% yaitu 9,203 mm, 10,208 $\mathrm{mm}$.

Dari hasil uji antibakteri yang telah dilakukan membutuhkan konsentrasi ekstrak yang tinggi untuk memberikan hasil yang positif sebagai antibakteri. Hal ini dikarenakan ekstrak yang digunakan adalah ekstrak kasar, maka perlu diadakan penyederhanaan ekstrak yaitu non polar, semi polar dan polar.

\section{KESIMPULAN}

Dari hasil penelitian dapat disimpulkan bahwa ekstrak etanol $70 \%$ daun tammate (Lannea coromandelica) dapat menghambat bakteri Propionilbacterium acnes dan Escherichia coli. Ekstrak etanol $70 \%$ daun tammate (Lannea coromandelica) dengan konsentrasi $10 \%$ dan $20 \%$ mengahasilkan diameter hambat terhadap bakteri Propionilbacterium acnes masing-masing $10,540 \mathrm{~mm}$, dan $12,418 \mathrm{~mm}$. Sedangkan pada bakteri Escherichia coli masing-masing 10,540 $\mathrm{mm}$, dan $12,418 \mathrm{~mm}$.

\section{SARAN}

Perlu dilakukan penyederhanaan komponen kimia terhadap sampel daun tammate (Lannea coromandelica) dan diperlukan uji lebih lanjut tentang isolasi senyawa-senyawa yang memiliki aktivitas antibakteri terhadap Propionilbacterium acnes dan Escherichia coli. Diharapkan kepada peneliti selanjutnya agar dapat melakukan penelitian terhadap mikroba lainnya.

\section{DAFTAR PUSTAKA}

Badan Pengawasan Obat dan Makanan Republik Indonesia. 2010. Acuan Sediaan Herbal, Volume Lima, Badan Pengawasan Obat dan Makanan, Jakarta.

Gana A.K. 2008. Effects of organc and inorganic fertilizers on sugarcane production. African Journal of General Agriculture. Vol. 4, No. 1, March 31.

Mumpuni Y. 2010. Cara Jitu Mengatasi Jerawat. Penerbit: Andi. Yogyakarta.

Prawirodiharjo E. .2014. Uji Aktivitas Antioksidan dan Uji Toksisitas Ekstrak Etanol $70 \%$ dan Ekstrak Air Kulit Batang Kayu Jawa (Lannea coromandelica). Jurusan Farmasi. Fakultas Kedokteran dan Ilmu Kesehatan UIN Syarif Hidayatullah. Jakarta.

Rahmadani F. 2015. Uji Aktivitas Antibakteri Dari Ekstrak Etanol 96\% Kulit Batang Kayu Jawa (Lannea coromandelica) Terhadap Bakteri Staphylococcus aureus, Escherichia coli, Helicobacter pylori, Pseudomonas aeruginosa. Jurusan Farmasi. Fakultas Kedokteran dan Ilmu Kesehatan UIN Syarif Hidayatullah. Jakarta.

Ramadhan A. 2015. Uji Aktivitas Antibakteri Senyawa-senyawa Hasil Modifikasi Struktur Etil p-Metoksisinamat Melalui Reaksi Esterifikasi Terhadap Bakteri Gram Negatif dan Gram Positif. Jurusan Farmasi. Fakultas Kedokteran dan Ilmu Kesehatan UIN Syarif Hidayatullah. Jakarta. 


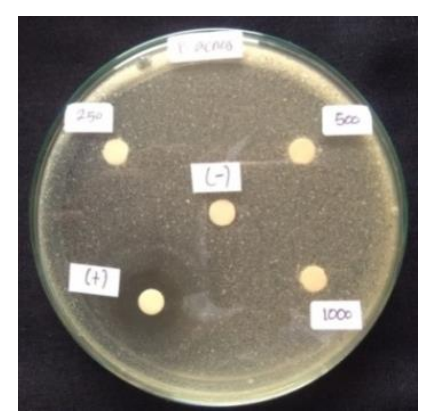

Gambar 1. Hasil uji diameter zona hambat ekstrak etanol 70\% daun tammate (Lannea Coromandelica) konsentrasi $0,025 \%, 0,05 \%, 0,1 \%$, kontrol positif klindamisin dan kontrol negatif DMSO terhadap bakteri Propionilbacterium acnes.

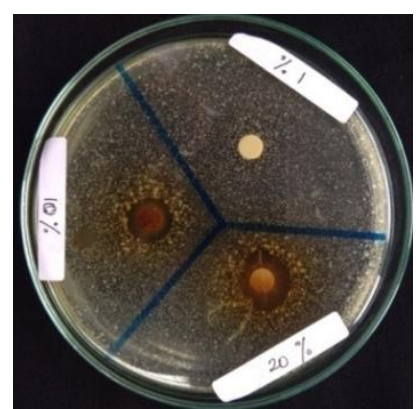

Gambar 2. Hasil uji diameter zona hambat ekstrak etanol $70 \%$ daun tammate (Lannea Coromandelica) konsentrasi 1\%, 10\% dan 20\% terhadap bakteri Propionilbacterium acnes.

\section{Hasil Uji Daya Antibakteri Bakteri Escherichia coli}

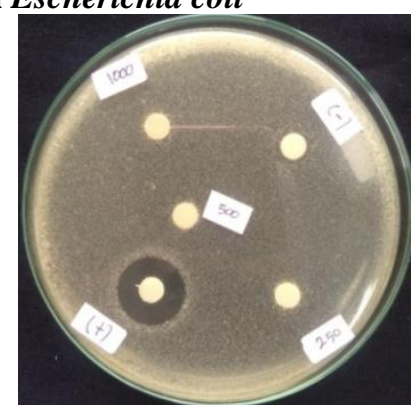

Gambar 3. Hasil uji diameter zona hambat ekstrak etanol $70 \%$ daun tammate (Lannea Coromandelica) konsentrasi $0,025 \%, 0,05 \%, 0,1 \%$, kontrol positif kloramfenikol dan kontrol negatif DMSO terhadap bakteri Escherichia coli.

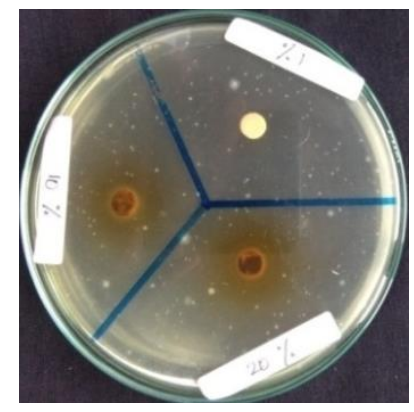

Gambar 4. Hasil uji diameter zona hambat ekstrak etanol 70\% daun tammate (Lannea Coromandelica) konsentrasi 1\%, 10\% dan 20\% terhadap bakteri Escherichia coli. 
Tabel 1.

Hasil pengukuran diameter zona hambat ekstrak daun tammate (Lannea coromandelica) terhadap bakteri Propionilbacterium acnes dan Escherichia coli (dilakukan dengan menggunakan jangka sorong)

\begin{tabular}{lll}
\hline \multirow{2}{*}{$\begin{array}{l}\text { Konsentrasi } \\
\text { Ekstrak }\end{array}$} & \multicolumn{2}{l}{ Diameter zona hambat $(\mathrm{mm})$ rata-rata } \\
\cline { 2 - 3 } $0,025 \%$ & 0 & 0 \\
$0,05 \%$ & 0 & 0 \\
$0,1 \%$ & 0 & 0 \\
$1 \%$ & 0 & 0 \\
$10 \%$ & 10,540 & 9,203 \\
$20 \%$ & 12,418 & 10,208 \\
Kontrol (-) & 0 & 0 \\
DMSO & & $\neq$ \\
Kontrol (+) & 15,474 & 15,676 \\
Klindamisin & & \\
Kontrol (+) & $\neq$ & \\
Kloramfenikol & &
\end{tabular}




\section{MEDIA FARMASI}

POLITEKNIK KESEHATAN MAKASSAR

Penasehat

Penanggung Jawab

Dewan Redaksi

Ketua

Anggota

Mitra Bestari

Alamat Redaksi
: Direktur Politeknik Kesehatan Kemenkes Makassar

: Ketua Jurusan Farmasi Politeknik Kesehatan

Kemenkes Makassar

: $\quad$ Santi Sinala, S,Si, M.Si, Apt

: Hendra Stevani, S.Si, M.Kes, Apt

Sisilia Teresia Rosmala Dewi, S.Si, M.Kes, Apt

Muli Sukmawaty, S.Farm, Apt

Muhammad Riswan, S.Kom

: $\quad$ Dr. Islamudin Ahmad, M.Si,Apt (Universitas Mulawarman)

DR. Rusli, Sp.FRS, Apt

DR. Hj. Nurisyah, M.Si, Apt (Poltekkes Makassar)

DR. Sesilia Rante Pakadang, M.Si, Apt (Poltekkes Makassar)

DR. H. Asyhari Asyikin, S.Farm, M.Kes (Poltekkes Makassar)

: Jurusan Farmasi

Politeknik Kesehatan Kementerian Kesehatan Makassar

J1. Baji Gau No.10 Makassar

Telp. 0411-854021, 830883 Fax. 0411-830883

Kode pos 90134

Website :

http://journal.poltekkes-mks.ac.id/ojs2/index.php/mediafarmasi/index 


\section{EDITORIAL}

Pembaca yang budiman, ucapan syukur Alhamdulillah kami panjatkan ke hadirat Tuhan Yang Maha Kuasa karena berkat rahmat dan anugerahNya sehingga penerbitan Vol. XIV No.2, Oktober 2018 MEDIA FARMASI POLITEKNIK KESEHATAN MAKASSAR dapat terlaksana dan telah mendapat legalitas sebagai media resmi dari Lembaga Ilmu Pengetahuan Indonesia (LIPI) dengan nomor penerbitan pISSN No. 0216-2083 dan e-ISSN No. 2622-0962.

Media Farmasi Politeknik Kesehatan Makassar merupakan suatu wadah dalam menampung aspirasi ilmiah sehingga dapat menggugah motivasi dan inovasi dari dosen di lingkup Jurusan Farmasi Politeknik Kesehatan Makassar serta artikel dari simpatisan untuk melakukan kajian ilmiah.

Media Farmasi Politeknik Kesehatan Makassar diterbitkan 2 kali dalam setahun yaitu pada bulan April dan Oktober. Sebagai majalah ilmiah, Media Farmasi mengembangkan misi dalam memajukan ilmu pengetahuan dan teknologi kesehatan khususnya di bidang farmasi

Akhirnya redaksi sangat berharap bahwa semua artikel yang disajikan dalam edisi ini dapat memberi apresiasi keilmuan di bidang kesehatan bagi kita semua. Oleh karena itu kritikan dan saran sangat kami harapkan demi kesempurnaan edisi-edisi selanjutnya.

Selamat membaca

Makassar, Oktober 2018

Redaksi 


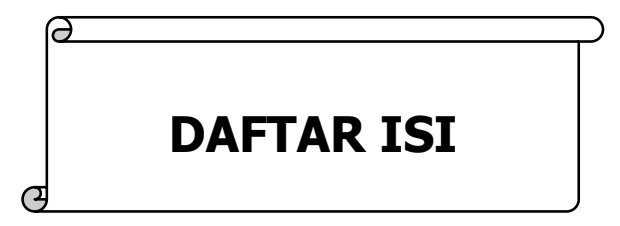

Pengaruh Pemberian Ekstrak Etanol Daun Afrika (Vernonia amygdalina

Del.) terhadap Kadar Asam Urat Darah Mencit Jantan (Mus musculus)

Jumain, Asmawati, Rini Karnita

Efektivitas Pemberian Rebusan Daun Pandan Wangi (Pandanus

Amaryllifolius Roxb.) terhadap Penurunan Kadar Glukosa Darah

Mencit (Mus musculus)

Amran Nur, Desi Reski Fajar, Musdalifah

Uji Efek Analgetik Infusa Jahe (Zingiber officinale Roscoe) terhadap Hewan Uji Mencit Jantan (Mus musculus)

Sisilia T. Rosmala Dewi, Hiany Salim.

Pengaruh Usia dan Tingkat Pendidikan terhadap Pemahaman Pasien

Setelah Pelayanan Informasi Obat di Puskesmas Makale Kabupaten

Tana Toraja Tahun 2018

Estherina Allo Payung, Septyani Mambela

Uji Daya Hambat Antibiotika Terhadap Bakteri Penyebab Infeksi

Saluran Kemih Di Rumah Sakit Salewangang Maros

Andi Dian Aulia Saudi, Rusdy

Uji Aktivitas Ekstrak Buah Pare (Momordica charantia L) terhadap Pertumbuhan Propionibacterium acnes

Dwi Rachmawaty Daswi, Asmawati

Analisis Kandungan Merkuri (Hg) pada Sediaan Krim Pemutih yang Beredar di Pasaran Kota Makassar dengan Menggunakan Metode Spektrofotometri Serapan Atom

Dedy Ma'ruf, Andi Asmawati, Ririn Muliana

Penentuan Total Polifenol Ekstrak Etanol Kulit Kecapi (Sandoricum koetjape) dari Lamasi Kabupaten Luwu

Santi Sinala, Minati, Alfrida Monica Salasa

Uji Potensi Antimikroba Hasil Fraksinasi Ekstrak Daun Kecombrang (Etlingera elatior) terhadap Candida albicans Penyebab Keputihan Pada Ibu Hamil

St. Ratnah, Alfrida Monica Salasa, H. Ismail Ibrahim 
Efek Konseling terhadap Tingkat Pengetahuan Ibu pada Terapi

Diare Balita

Khaerani, Surya Ningsi, Andi Try Resti Fauziah Sahib

Uji Daya Hambat Daun Tammate (Lannea coromandelica) terhadap

Bakteri Propionibacterium acnes dan Escherichia coli

Nurlaela, Abd.Karim, Taufiq Dalming

Efektivitas Ekstrak Air Buah Belimbing Wuluh (Averrhoa bilimbi)

Terhadap Pertumbuhan Propionibacterium acnes

Arisanty, Rara Puspa Dewi

Aktivitas Perasan Biji Pinang (Areca catechu L.) terhadap Pertumbuhan

Streptococcus mutans

Ikke Nurjanna, Hendra Stevani, Ratnasari Dewi

Evaluasi Tingkat Kepuasaan Pasien terhadap Pelayanan Kefarmasin di Depo IGD

Rumah Sakit TK II Pelamonia Makassar

Rahmawati, Desi Reski Fajar, Ira Widya Sari

78

Analisis Lama Waktu Tunggu Pelayanan Resep di Apotek BPJS

Rawat Jalan Rumah Sakit Pelamonia

Veronika Dampung, Ita Purnama Sari, Citra Rahayu, Rusli 